\title{
GT-2002-30626
}

\section{ENVIRONMENTAL BARRIER COATINGS HAVING A YSZ TOP COAT}

\author{
Kang N. Lee \\ Cleveland State University \\ NASA Glenn Research Center \\ Cleveland, $\mathrm{OH} 44135$, USA
}

\begin{abstract}
Environmental barrier coatings (EBCs) with a Si bond coat, a yttria-stabilized zirconia (YSZ) top coat, and various intermediate coats were investigated. EBCs were processed by atmospheric pressure plasma spraying. The EBC durability was determined by thermal cycling tests in water vapor at $1300^{\circ} \mathrm{C}$ and $1400^{\circ} \mathrm{C}$, and in air at $1400^{\circ} \mathrm{C}$ and $1500^{\circ} \mathrm{C}$. $\mathrm{EBCs}$ with a mullite $\left(3 \mathrm{Al}_{2} \mathrm{O}_{3} \cdot 2 \mathrm{SiO}_{2}\right)+\mathrm{BSAS}\left(1-\mathrm{xBaO} \cdot x \mathrm{SrO} \cdot \mathrm{Al}_{2} \mathrm{O}_{3} \cdot 2 \mathrm{SiO}_{2}\right)$ intermediate coat were more durable than $\mathrm{EBCs}$ with a mullite intermediate coat, while EBCs with a mullite/BSAS duplex intermediate coat resulted in inferior durability. The improvement with a mullite+BSAS intermediate coat was attributed to enhanced compliance of the intermediate coat due to the addition of a low modulus BSAS second phase. Mullite+BSAS/YSZ and BSAS/YSZ interfaces produced a low melting $\left(<1400^{\circ} \mathrm{C}\right)$ reaction product, which is expected to degrade the EBC performance by increasing the thermal conductivity. EBCs with a mullite+BSAS/graded mullite+YSZ intermediate coat showed the best durability among the EBCs investigated in this study. This improvement was attributed to diffused CTE mismatch stress and improved chemical stability due to the compositionally graded mullite+YSZ layer.
\end{abstract}

\section{INTRODUCTION}

Silicon-based ceramics, such as silicon carbide fiber reinforced silicon carbide ( $\mathrm{SiC} / \mathrm{SiC}$ ) ceramic matrix composites (CMC), are prime candidates for the hot section components of next generation gas turbine engines. Silicon-based ceramics, however, suffer from rapid surface recession in combustion environments due to the volatilization of silica scale via reaction with water vapor.[1-4] An external environmental barrier coating (EBC) is a logical approach to achieving protection and long-term stability.

The early coatings work for Si-based ceramics was initiated to provide protection from contact stress damage or molten salt corrosion. Garrett Turbine Engine Company initiated coatings work in the late 1970s - early 1980s to seek solutions to the contact stress damage on Si-based ceramics.[5,6] Various refractory oxides, such as $\mathrm{Al}_{2} \mathrm{O}_{3}, \mathrm{ZrO}_{2}, \mathrm{Cr}_{2} \mathrm{O}_{3}, \mathrm{AlN}$, and mullite $\left(3 \mathrm{Al}_{2} \mathrm{O}_{3} \cdot 2 \mathrm{SiO}_{2}\right)$, were investigated by plasma spraying, chemical vapor deposition (CVD), sol-gel, and electron beamphysical vapor deposition (EB-PVD). In 1980s, Solar Turbines developed plasma-sprayed refractory oxide coatings for hot corrosion protection of $\mathrm{SiC}$ ceramics.[7,8] Among the coatings investigated, which included $\mathrm{Al}_{2} \mathrm{O}_{3}, \mathrm{YSZ}$, mullite, zircon $\left(\mathrm{ZrSiO}_{4}\right)$, and $\mathrm{Y}_{2} \mathrm{O}_{3}$, single layer mullite coatings showed the best durability in hot corrosion test at $760-1204^{\circ} \mathrm{C}$. In the early 1990s, NASA Glenn Research Center (GRC) modified the plasma spray process to deposit fully crystalline mullite coatings that exhibited dramatically improved hot corrosion and thermal cycling resistance compared to conventionally plasmasprayed mullite coatings at temperatures up to $1300^{\circ} \mathrm{C}$. $[9,10]$ In the mid 1990s, Boston University developed a mullite coating by CVD [11], which was later modified at ORNL.[12] Thin $(2 \sim 10 \mu \mathrm{m})$, dense CVD mullite coatings provided excellent protection in $\mathrm{Na}_{2} \mathrm{SO}_{4}$. Other coating systems for Si-based ceramics investigated in $1980 \mathrm{~s}-1990 \mathrm{~s}$ are summarized in Ref.[13].

By the mid 1990s, the volatilization of silica in water vapor and the resulting surface recession of silicon-based ceramics emerged as a showstopper for the application of these materials 
in combustion environments. This shifted the focus of coatings research to protection from water vapor.[14-16] Mullite coatings also lost silica in water vapor through volatilization, leaving a porous alumina layer on the surface in a simulated combustion environment, while mullite/YSZ duplex coatings effectively suppressed the silica volatilization (Fig. 1).[15] Mullite/YSZ duplex coatings, however, eventually suffered from water vapor attack as water vapor penetrated through cracks in the coating and attacked the substrate.

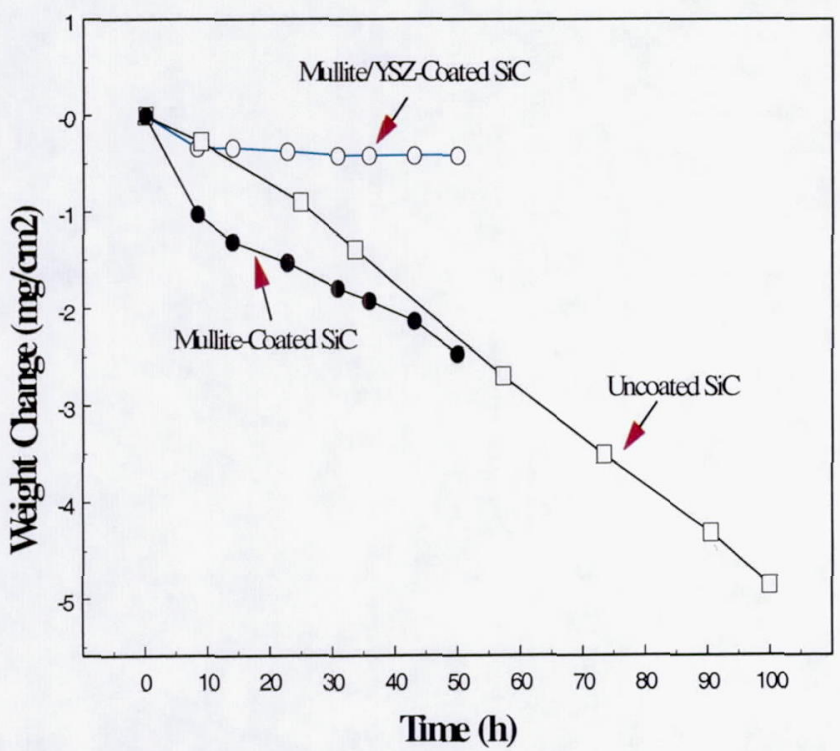

Figure 1. Specific weight change of coated and uncoated $\mathrm{SiC}$ in a high pressure burner rig environment $\left(1230^{\circ} \mathrm{C}, 6 \mathrm{~atm}, \mathrm{pH}_{2} \mathrm{O} \sim\right.$ 0.6 , gas velocity $\sim 24 \mathrm{~m} / \mathrm{s}$ ) [15]

A new, crack-resistant coating system, consisting of a silicon bond coat, a mullite or modified mullite (mullite+BSAS) intermediate coat, and a BSAS $\left(1-\mathrm{xBaO} \cdot \mathrm{xSrO} \cdot \mathrm{Al}_{2} \mathrm{O}_{3} \cdot 2 \mathrm{SiO}_{2}\right)$ top coat, was developed as a part of the HSR-EPM (High Speed Research-Enabling Propulsion Materials) Program in joint research by NASA, GE, and Pratt \& Whitney.[17,18] The EBCs developed in the EPM Program were scaled up and applied on $\mathrm{SiC} / \mathrm{SiC}$ composite combustor liners by Pratt \& Whitney in three Solar Turbines Centaur 50S turbine engines under DOE's Ceramic Stationary Gas Turbine Engine Program. $[18,19]$ The combined operation of the three engines has resulted in the accumulation of over 24,000 hours without failure $\left(1250^{\circ} \mathrm{C}\right.$ maximum combustor liner temperature), with the engine used by Texaco in Bakersfield, CA, accumulating about 14,000 hours.

In our laboratory, research is underway to develop EBCs capable of $1482^{\circ} \mathrm{C}\left(2700^{\circ} \mathrm{F}\right)$ EBC surface temperature and $166^{\circ} \mathrm{C}\left(300^{\circ} \mathrm{F}\right)$ temperature gradient. Thorough understanding of current EBCs should provide the foundation upon which development of future EBCs can be based. Therefore, a task was undertaken to characterize current $\mathrm{EBCs}$, with the main focus on determining the upper temperature limit. Areas investigated include environmental/chemical durability, phase stability, and thermal conductivity.[20-22] It was suggested based on chemical/environmental durability and silica volatility that the upper temperature limit of EBCs based on silicon, mullite, and BSAS, for over a thousand hours of life, is $\sim 1400^{\circ} \mathrm{C}$.[20] BSAS-silica (thermally grown) reaction produces a low melting $\left(\sim 1300^{\circ} \mathrm{C}\right) \quad \mathrm{Al}_{2} \mathrm{O}_{3}-\mathrm{SiO}_{2}-\mathrm{BaO}-\mathrm{SrO}$ reaction product, leading to $\mathrm{EBC}$ delamination, while BSAS is projected to suffer significant recession $(20 \sim 60 \mu \mathrm{m}$ after $1000 \mathrm{~h}$ at $1400^{\circ} \mathrm{C}, 6 \mathrm{~atm}, \mathrm{pH}_{2} \mathrm{O}=0.6$, gas velocity $=24 \mathrm{~m} / \mathrm{s}$ ). The $\mathrm{EBC}$ on Solar Turbines $\mathrm{SiC} / \mathrm{SiC}$ liners showed substantial BSAS recession in some areas after the $14,000 \mathrm{~h}$ engine test.[19] Two approaches are taken in our research to develop EBCs with higher temperature capability. One is to apply a low thermal conductivity TBC top coat, such as YSZ, and the other is to develop high melting, low CTE oxide EBCs. This paper discusses the status of the development of EBCs consisting of a $\mathrm{Si}$ bond coat, a YSZ top coat, and various intermediate coats.

\section{EXPERIMENTAL}

Table I. EBC systems investigated ( $500 \sim 750 \mu \mathrm{m}$ thick)

\begin{tabular}{|c|c|c|}
\hline Bond coat & Intermediate coat & Top coat \\
\hline $\mathrm{Si}$ & mullite & YSZ \\
\hline $\mathrm{Si}$ & mullite+BSAS & YSZ \\
\hline $\mathrm{Si}$ & mullite/BSAS & YSZ \\
\hline $\mathrm{Si}$ & mullite+BSAS/graded mullite+YSZ & YSZ \\
\hline
\end{tabular}

Table I lists EBC systems investigated in this study. EBCs were applied by plasma spraying onto sintered, monolithic $\mathrm{SiC}$ (Hexoloy $^{\mathrm{TM}}$, Carborundum, Niagara Falls, NY) and melt infiltrated (MI) $\mathrm{SiC} / \mathrm{SiC}$ composites (GE Power Systems Composites, Newark, Delaware). Only one face of test coupons $(2.5 \mathrm{~cm} \times 0.6 \mathrm{~cm} \times 0.15 \mathrm{~cm})$ was coated. Silicon powder was purchased from Atlantic Equipment Engineers (Bergenfield, NJ), mullite powder from Cerac, Inc. (Milwaukee, WI), BSAS powder from H.C. Starck Inc. (Newton, MA) and Praxair Specialty Ceramics (Woodinville, WA), and mullite+YSZ mixtures from Cambridge Microtech (Cambridge, MA).

Table II. Test conditions

\begin{tabular}{|l|c|c|}
\hline Environment & $\begin{array}{l}\text { steam }\left(90 \% \quad \mathrm{H}_{2} \mathrm{O}-\right. \\
\left.10 \% \mathrm{O}_{2}\right)\end{array}$ & ambient air \\
\hline Temperature $\left({ }^{\circ} \mathrm{C}\right)$ & 1300,1400 & 1400,1500 \\
\hline Cycle frequency (hour) & 1 & 20 \\
\hline Gas velocity $(\mathbf{c m} / \mathbf{s e c})$ & 2.2 & 0 \\
\hline Total pressure $(\mathbf{a t m})$ & 1 & 1 \\
\hline Substrate & $\mathrm{MI} \mathrm{SiC} / \mathrm{SiC}$ & sintered SiC \\
\hline Silicon bond coat & yes & no \\
\hline
\end{tabular}

Table II lists test conditions. The steam environment was generated by pumping water into a cyclic rig using a peristaltic pump. The cyclic rig consists of a high purity alumina tube (99.8\% purity) and a vertical tube cycling furnace. The 
pumped water was rapidly vaporized by passing through quartz wool at $\mathrm{T}>300^{\circ} \mathrm{C}$ in flowing oxygen. A box furnace was used for the ambient air environment. The use of monolithic $\mathrm{SiC}$ and the absence of $\mathrm{Si}$ bond coat in the ambient air exposure were to eliminate the melting of silicon $\left(\mathrm{mp}=1416^{\circ} \mathrm{C}\right)$ in the $1500^{\circ} \mathrm{C}$ exposure. Tests in the ambient air were to investigate the $\mathrm{EBC}$ chemical stability. The progress of degradation was determined by visual observation, cross-sectional examination using scanning electron microscopy (SEM), and chemical analysis using energy dispersive spectroscopy (EDS). Phase transformations in YSZ were determined by X-ray diffraction.

\section{RESULTS AND DISCUSSION}

\section{Si/Mullite/YSZ}

EBCs on $\mathrm{MI} \mathrm{SiC} / \mathrm{SiC}$ remained adherent after a $100 \mathrm{~h}$ exposure at $1300^{\circ} \mathrm{C}$ in steam. At $1400^{\circ} \mathrm{C}$ after a $100 \mathrm{~h}$ exposure in steam, the $\mathrm{EBC}$ completely peeled off, typically along the $\mathrm{Si} /$ mullite interface or through the $\mathrm{Si}$ bond coat, and subsequently curled up toward the YSZ side. The direction of the curling indicates that the YSZ coating shrunk more than the mullite coating during cooling. The larger shrinkage of the YSZ coating is attributed to YSZ sintering. The sintering of plasma-sprayed YSZ on $\mathrm{SiC}$ during thermal exposures is reported in Ref. [23].

The YSZ shrinkage and the YSZ-mullite CTE mismatch $\left(\sim 10 \times 10^{-6} /{ }^{\circ} \mathrm{C}\right.$ for YSZ vs. $\sim 5 \times 10^{-6} /{ }^{\circ} \mathrm{C}$ for mullite[24] $)$ are expected to generate in-plane tensile stress in the YSZ layer, causing cracking through the thickness of YSZ. YSZ phase stability is another issue for long-term durability. A nonequilibrium tetragonal phase forms when partially stabilized zirconia-yttria is plasma-sprayed.[25,26] This phase decomposes slowly at high temperatures into a high-yttria cubic phase and a low-yttria tetragonal phase. This equilibrium tetragonal phase transforms on cooling to the monoclinic phase. According to X-ray diffraction, the YSZ top coat lost most of the nonequilibrium tetragonal phase after as early as $20 \mathrm{~h}$ at $1300^{\circ} \mathrm{C}$. This results in a reversible phase transformation between the tetragonal phase and the monoclinic phase on thermal cycling, adding additional stresses on the EBC.

Mullite EBCs fail due to enhanced oxidation via water vapor that penetrates through cracks in the mullite and oxidizes the substrate.[15] Adding a YSZ top coat does not prevent the penetration of water vapor, due to cracking in the YSZ. Instead, the YSZ top coat accelerates the EBC spallation by adding more stresses.

\section{Si/Mullite+BSAS/YSZ}

EBCs on $\mathrm{MI} \mathrm{SiC/SiC}$ remained adherent after a $100 \mathrm{~h}$ exposure at $1300^{\circ} \mathrm{C}$ in steam. At $1400^{\circ} \mathrm{C}$ after $240 \mathrm{~h}$ in steam, a partial spallation was observed, typically along the $\mathrm{Si} /$ mullite+BSAS interface or through the $\mathrm{Si}$ bond coat. This is an improvement compared to the $\mathrm{Si} /$ mullite/YSZ EBC, which completely spalled after a $100 \mathrm{~h}$ exposure at $1400^{\circ} \mathrm{C}$ in steam. The mullite+BSAS coating possesses superior crack resistance compared to the mullite coating.[17] The young's modulus of mullite $(\sim 150 \mathrm{GPa}[27])$ is larger than that of BSAS $(\sim 100 \mathrm{GPa}$ [28]) by a factor of about 1.5. Assuming that plasma-sprayed coatings of mullite and BSAS will maintain a similar modulus ratio, it is proposed that the improved crack resistance of the mullite+BSAS coating is the result of improved compliance due to the addition of a low modulus BSAS phase. Significant cracking was also observed, typically through the thickness of YSZ and along the mullite+BSAS/YSZ interface (Fig. 2).

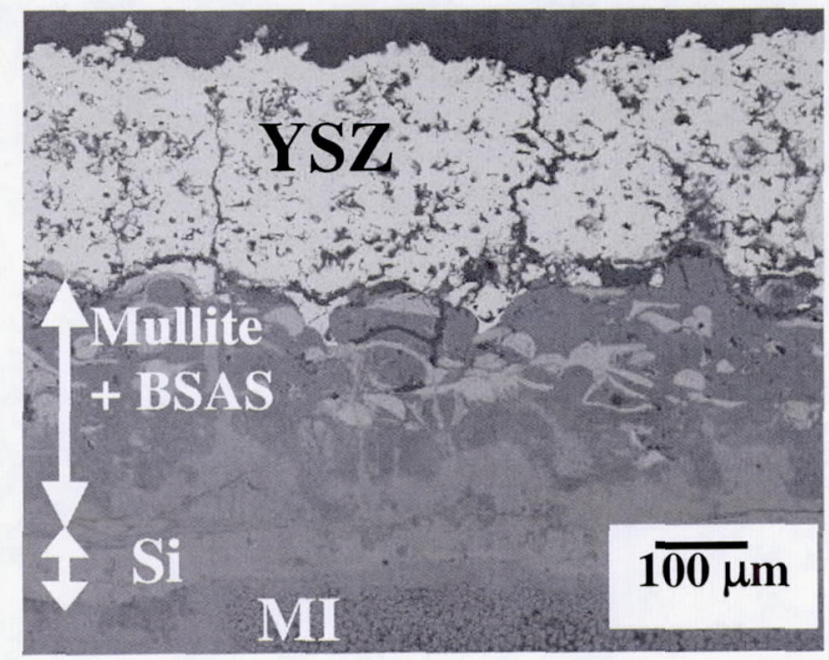

Figure 2 Cross-section of the Si/mullite+BSAS/YSZ EBC on $\mathrm{MI} \mathrm{SiC/SiC}$ after $240 \mathrm{~h}$ at $1400^{\circ} \mathrm{C}$ in steam.

A significant BSAS-silica reaction was observed at the $\mathrm{Si} /$ mullite+BSAS interface, especially on delaminated or spalled areas. This indicates that oxidation of silicon and the subsequent BSAS-silica reaction contributed to the delamination and spalling of the EBC. It is proposed that the combination of EBC stresses and the environmental/chemical degradation at the $\mathrm{Si} /$ mullite+BSAS interface is mainly responsible for the EBC spallation. The bright phase in the mullite+BSAS intermediate coat in Fig. 2 is BSAS, elongated in the $\mathrm{y}$ direction due to the splat formation during the deposition, and the dark phase is mullite. The morphology of the EBC did not change much from the as-processed EBC, except for the $\mathrm{Si} /$ mullite+BSAS interface, which became fuzzy due to the BSAS-silica reaction. In some areas, pores in the YSZ top coat were filled with a reaction product, which appears to have been molten at $1400^{\circ} \mathrm{C}$, due to a reaction at the mullite+BSAS/YSZ interface.

The (mullite+BSAS)-YSZ reaction became more pronounced at $1500^{\circ} \mathrm{C}$. Figure 3 shows the mullite+BSAS/YSZ interface after $20 \mathrm{~h}$ at $1500^{\circ} \mathrm{C}$ in air. Note the changes in the morphology of the intermediate coat compared to the EBC in 
Fig. 2: the bright phase became smaller in size and more closely spaced. Also note that pores in the YSZ are completely filled with a reaction product. EDS analysis detected only aluminum from the dark phase (area A in Fig. 3), and aluminum, silicon, barium (strontium peak overlaps with the silicon peak), yttrium, and calcium from the bright phase (area B in Fig. 3). It appears that silica from the mullite and yttria from the YSZ reacted with BSAS, forming the molten reaction product. The calcium is speculated to come from impurities in powders or from insulation refractory materials of the box furnace.
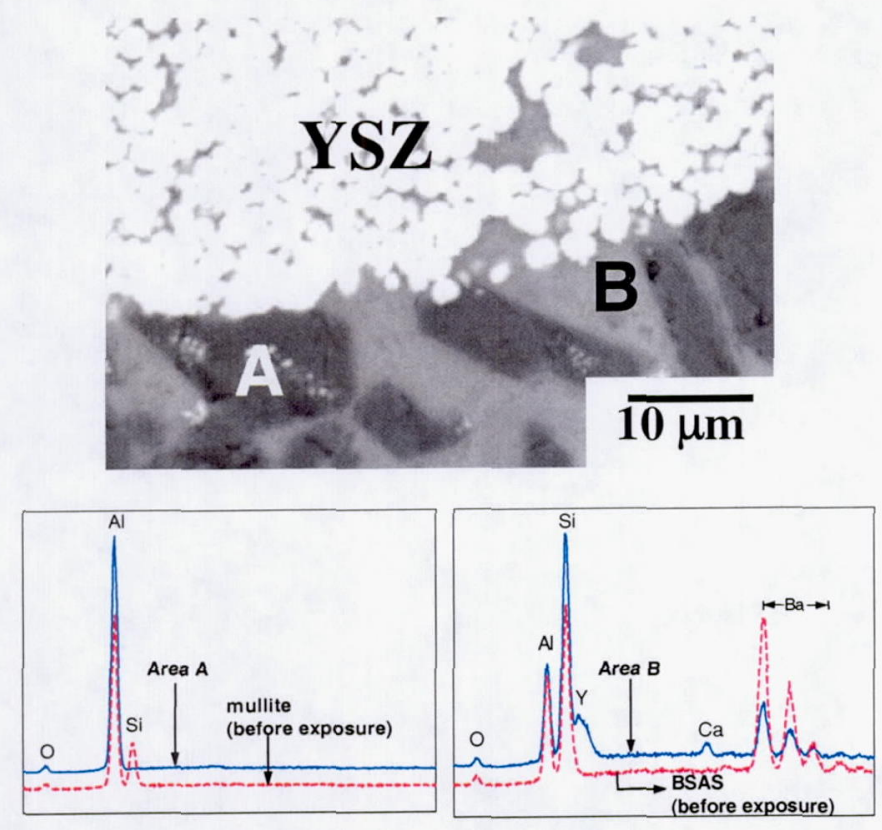

Figure 3 Cross-section and EDS spectrum from the $\mathrm{Si} /$ mullite+BSAS/YSZ EBC on MI SiC/SiC after $20 \mathrm{~h}$ at $1500^{\circ} \mathrm{C}$ in air

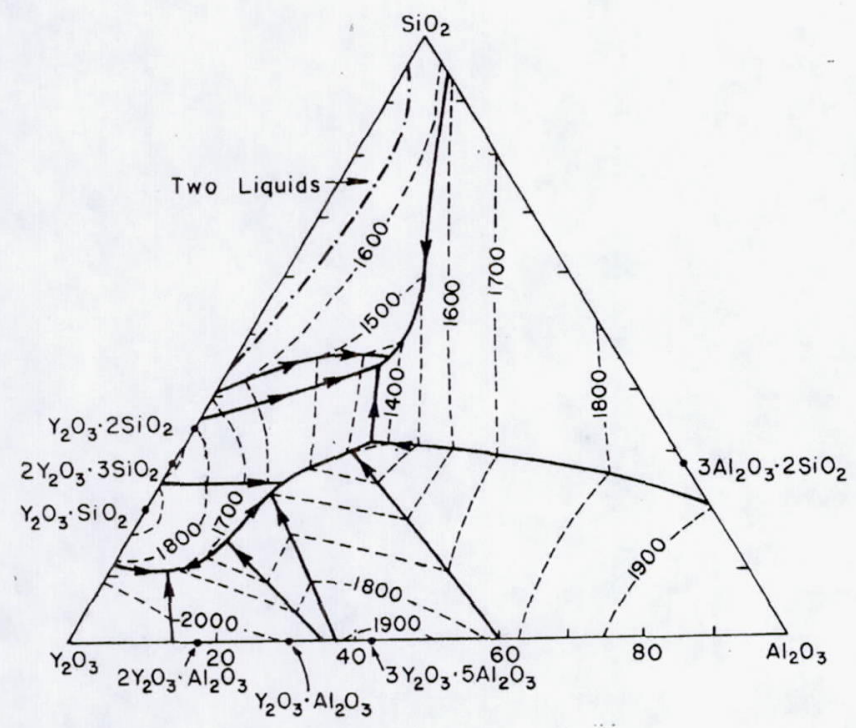

Figure $4 \mathrm{Y}_{2} \mathrm{O}_{3}-\mathrm{Al}_{2} \mathrm{O}_{3}-\mathrm{SiO}_{2}$ phase diagram [29]
According to the $\mathrm{Y}_{2} \mathrm{O}_{3}-\mathrm{Al}_{2} \mathrm{O}_{3}-\mathrm{SiO}_{2}$ phase diagram (Fig. 4), the ternary system is capable of forming compounds with the melting point as low as $\sim 1400^{\circ} \mathrm{C}$ even without $\mathrm{BaO}, \mathrm{SrO}$, and $\mathrm{CaO}$.[29] The presence of these alkali earth metal oxides will further reduce the melting point of reaction products in the ternary system. A molten reaction product is expected to increase EBC thermal conductivity because it tends to fill open spaces in the EBC. The thermal conductivity of BSAS-coated $\mathrm{MI} \mathrm{SiC/SiC} \mathrm{continuously} \mathrm{increased} \mathrm{during} \mathrm{a} \mathrm{thermal} \mathrm{exposure,}$ which was attributed to the formation of a low melting reaction product by the BSAS-silica reaction.[22] The reaction product moved to the YSZ surface forming a molten surface layer, which is expected to be swept away by a high velocity combustion gas. Therefore, the mullite+BSAS/YSZ interface should be avoided to prevent the formation of the low melting reaction product.

\section{$\underline{\text { Si/Mullite/BSAS/YSZ }}$}

EBCs were completely spalled along the BSAS/YSZ interface after a $100 \mathrm{~h}$ exposure at $1300^{\circ} \mathrm{C}$ and $1400^{\circ} \mathrm{C}$ in steam. This suggests a weak BSAS-YSZ adherence. At $1400^{\circ} \mathrm{C}$ after $120 \mathrm{~h}$ in air, the EBC was partially delaminated along the BSAS/YSZ interface. Significant reactions were observed at the BSAS/YSZ and the mullite/BSAS interfaces. Figure 5 shows the BSAS/YSZ and the mullite/BSAS interfaces after $120 \mathrm{~h}$ at $1400^{\circ} \mathrm{C}$ in air.
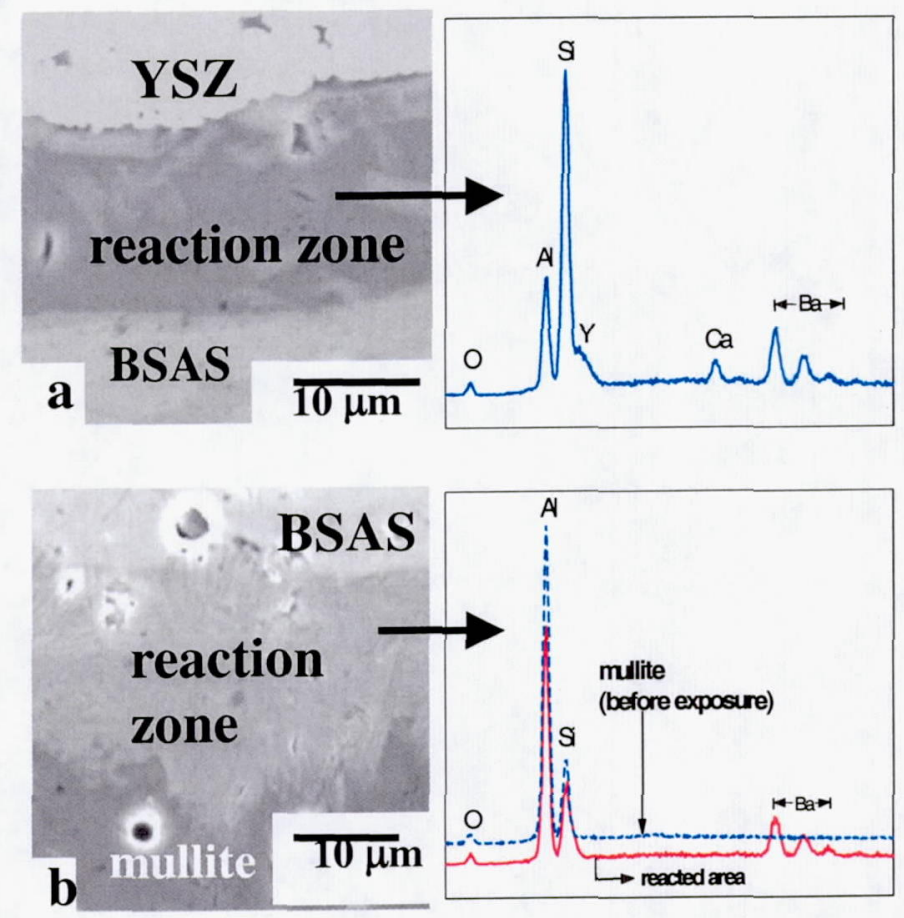

Figure 5 Cross-section and EDS spectrum from (a) BSAS/YSZ and (b) mullite/BSAS interfaces after $120 \mathrm{~h}$ at $1400^{\circ} \mathrm{C}$ in air 
The EDS spectrum from the BSAS/YSZ reaction zone (Fig. 5a) is similar to that of the reaction product at the mullite+BSAS/YSZ interface. Similar to the $\mathrm{Si} /$ mullite+BSAS/YSZ EBC, pores in the YSZ were filled with the reaction product, indicating that the reaction product was molten at $1400^{\circ} \mathrm{C}$. The EDS spectrum from the mullite/BSAS reaction zone (Fig. 5b) contains aluminum, silicon, and barium. The intensity of these peaks is between that of mullite and BSAS peaks, suggesting that the reaction zone is the result of interdiffusion between the two layers. There were no indications that the reaction zone was molten at $1400^{\circ} \mathrm{C}$. The mulliteBSAS reaction appears to be benign to $\mathrm{EBC}$ durability at least for the short-term exposure conducted in this study. Significant diffusion between mullite and BSAS was also observed in the $\mathrm{Si} /$ mullite/BSAS EBC after a $1000 \mathrm{~h}$ exposure at $1300^{\circ} \mathrm{C}$ in steam, with no obvious detrimental effects on EBC durability.[20]

\section{Si/Mullite+BSAS/Graded Mullite+YSZ/YSZ}

The mullite/YSZ interface maintains excellent chemical stability at temperatures up to $1500^{\circ} \mathrm{C}$, suggesting that mullite can be an effective chemical barrier between mullite+BSAS and YSZ. One way to alleviating the CTE mismatch stress between the YSZ and the mullite+BSAS coatings is by creating a compositionally graded intermediate coat, starting with mullite at the bottom then gradually increasing the YSZ/mullite ratio towards the YSZ top coat. A graded layer of mullite/mullite $+25 \mathrm{v} / \mathrm{o} \quad \mathrm{YSZ} / \mathrm{mullite}+50 \mathrm{v} / \mathrm{o} \mathrm{YSZ} / \mathrm{mullite}+75 \mathrm{v} / \mathrm{o}$ YSZ was applied between the mullite+BSAS and the YSZ coatings. Figure 6 shows the cross-section of $\mathrm{Si} /$ mullite+BSAS/graded mullite+YSZ/YSZ EBC $(\sim 750 \mu \mathrm{m}$ thick) on $\mathrm{MI} \mathrm{SiC} / \mathrm{SiC}$ after $370 \mathrm{~h}$ at $1400^{\circ} \mathrm{C}$ in steam. The EBC showed a partial spallation after the exposure, an improvement compared to the Si/mullite+BSAS/YSZ EBC, in which a partial spallation was observed after $240 \mathrm{~h}$ at $1400^{\circ} \mathrm{C}$ in steam.

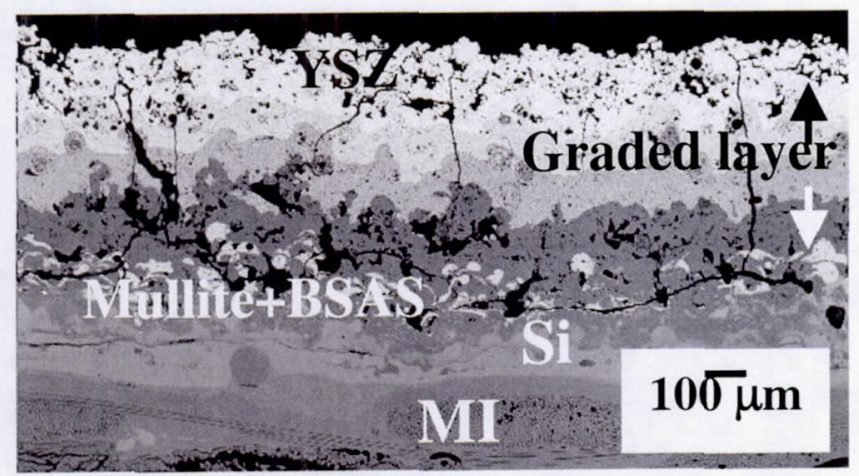

Figure 6 Cross-section of the Si/mullite+BSAS/graded mullite+YSZ/YSZ EBC on MI SiC/SiC after $370 \mathrm{~h}$ at $1400^{\circ} \mathrm{C}$ in steam
The failure mode of the EBC was more complex than the other EBCs. Although the spallation occurred typically along the $\mathrm{Si} /$ mullite+BSAS interface or through the $\mathrm{Si}$ bond coat, some areas spalled through the mullite+BSAS or the mullite layers. Significant cracking was also observed, typically through the thickness of graded mullite+YSZ/YSZ and along or near the mullite+BSAS/mullite interface as shown in Fig. 6 . There were no indications of low melting reaction products within the EBC, except for the BSAS-silica reaction product at the Si/mullite+BSAS interface. The superior durability of the $\mathrm{Si} /$ mullite+BSAS/graded mullite+YSZ/YSZ EBC compared to the other EBCs investigated in this study is attributed to the improved chemical stability and the diffused CTE mismatch stress due to the compositionally graded mullite+YSZ layer.

\section{SUMMARY}

EBCs with a Si bond coat, a YSZ top coat, and various intermediate coats were applied by plasma spraying onto $\mathrm{SiC}$ ceramics. Coated coupons were tested in steam and in ambient air to investigate the EBC durability.

The Si/mullite/YSZ EBC completely spalled along the $\mathrm{Si} /$ mullite interface or through the $\mathrm{Si}$ bond coat after a $100 \mathrm{~h}$ exposure at $1400^{\circ} \mathrm{C}$ in steam. The $\mathrm{Si} /$ mullite+BSAS/YSZ EBC showed a partial spallation after $240 \mathrm{~h}$ at $1400^{\circ} \mathrm{C}$, indicating improved EBC durability compared to the Si/mullite/YSZ EBC. The mullite+BSAS/YSZ interface, however, produced a low melting reaction product $\left(<1400^{\circ} \mathrm{C}\right)$, which filled pores in the YSZ. A low melting reaction product is detrimental to EBC performance by increasing the thermal conductivity. Further improvement in EBC durability was achieved with a mullite+BSAS/graded mullite+YSZ intermediate coat, which showed a partial spallation after $370 \mathrm{~h}$ at $1400^{\circ} \mathrm{C}$ in steam. The improvement with the mullite+BSAS intermediate coat is attributed to the enhanced compliance of the intermediate coat due to the addition of a low modulus BSAS second phase, while the additional improvement with the mullite+BSAS/graded mullite+YSZ intermediate coat is attributed to diffused CTE mismatch stress and improved chemical stability due to the graded mullite+YSZ layer.

Replacing the mullite intermediate coat with a mullite/BSAS duplex layer was not beneficial to EBC durability. Not only the BSAS/YSZ interface was a "weak link", leading to a complete EBC spallation along the interface after a $100 \mathrm{~h}$ exposure at $1300^{\circ} \mathrm{C}$ and $1400^{\circ} \mathrm{C}$ in steam, but also the BSAS/YSZ interface produced a low melting reaction product similar to that formed at the mullite+BSAS/YSZ interface.

The combination of a "weak link", a weak interface in the EBC caused by a defect or degradation, and the stress caused by YSZ sintering, CTE mismatch, and YSZ phase instability is mainly responsible for the failure of EBCs investigated in this study. The location of the "weak link" depends on the design of 
intermediate coat. The $\mathrm{Si} /$ mullite interface is the "weak link"

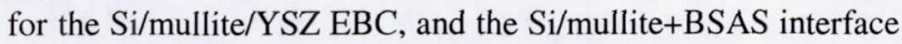
for the $\mathrm{Si} /$ mullite+BSAS/YSZ and the $\mathrm{Si} /$ mullite+BSAS/graded mullite+YSZ/YSZ EBCs. The "weak link" along the Si/mullite interface is due to oxidation of the $\mathrm{Si}$ bond coat, while the "weak link" along the Si/mullite+BSAS interface is due to the combination of $\mathrm{Si}$ bond coat oxidation and the subsequent BSAS-silica reaction. The BSAS/YSZ interface is the "weak link" for the Si/mullite/BSAS/YSZ EBC, which is due to the weak BSAS-YSZ adherence.

A complex thermal/environmental barrier coating system for silicon-containing materials, consisting of a silicon bond coat (optional), a multilayer intermediate coat and a YSZ TBC top coat, is described in Ref. [30]. The multilayer intermediate coat consists of a mullite-containing layer, an alkaline earth metal aluminosilicate (preferably BSAS) layer, and a YSZcontaining layer (discrete or compositionally graded) that also contains mullite, alumina, and/or alkaline earth metal aluminosilicate (preferably BSAS). No durability data were reported in the reference, however, in light of the findings in this study, chemical reactions between the alkaline earth metal aluminosilicate component and YSZ in the multilayer intermediate coat are likely to become a durability issue.

It should be noted that $1400^{\circ} \mathrm{C}$ is too high for the $\mathrm{EBC} /$ substrate interface of current $\mathrm{EBC}$ systems, causing the detrimental BSAS-silica reaction. If the $\mathrm{EBC} /$ substrate temperature is kept at or below $1316^{\circ} \mathrm{C}$ (current EBC/substrate temperature goal) the BSAS-silica reaction will be significantly reduced, presumably resulting in an extended EBC life.

\section{CONCLUSIONS}

Current EBCs fail by delamination and spallation along a "weak link". The stress caused by a YSZ layer accelerates the failure. A key source for the creation of the "weak link" is environmental/chemical degradation. This proposed failure mechanism suggests that key material properties for long life EBCs should include environmental/chemical stability, low CTE, low modulus, sinter resistance, low thermal conductivity, and phase stability.

A test facility capable of producing a heat flux high enough to generate necessary temperature gradients as well as thermal cycling and steam environments is needed for more efficient identification of promising EBCs.

\section{ACKNOWLEDGEMENTS}

I am grateful to G. W. Leissler of QSS/NASA GRC for the preparation of plasma spray coatings, S. L. Leissler of QSS/NASA GRC for the metallographic preparation of EBCs, and R. Garlick of NASA GRC for X-ray diffraction. I am also grateful to J. I. Eldridge of NSAS GRC and D. Zhu of OAI/NASA GRC for many helpful discussions. This work was supported by the NASA Ultra Efficient Engine Technology (UEET) Program.

\section{REFERENCES}

1. Opila, E. J. and Hann, R., 1997, "Paralinear Oxidation of CVD SiC in Water Vapor," J. Am. Ceram. Soc., 80[1], pp. 197-205.

2. Smialek, J. L., Robinson, R. C., Opila, E. J., Fox, D. S., and Jacobson, N. S., 1999, "SiC and $\mathrm{Si}_{3} \mathrm{~N}_{4}$ Scale Volatility under Combustor Conditions," Adv. Composite Mater., 8[1], pp. 33-45.

3. More, K. L., Tortorelli, P. F., Ferber, M. K., Walker, L. R., Keiser, J. R., Miriyala, N., Brentnall, W. D., and Price, J. R., June 7-10, 1999, "Exposure of Ceramics and Ceramic Matrix Composites in Simulated and Actual Combustor Environments," ASME paper 99-GT-292, presented at the International Gas Turbine and Aeroengine Congress and Exposition, Indianapolis, IN, USA.

4. Ferber, M. K., Lin, H. T., Parthasarathy, V., and Brentnall, W. D., June 7-10, 1999, "Degradation of Silicon Nitrides in High Pressure, Moisture Rich Environments," ASME paper 99-GT-265, presented at the International Gas Turbine and Aeroengine Congress and Exposition, Indianapolis, IN, USA.

5. Garrett Turbine Engine Company, July 1981, "Advanced Gas Turbine (AGT) Powertrain System Development for Automotive Applications," Second Semiannual Progress Report (July-December, 1980), NASA CR-165329, pp. 6782.

6. Richerson, D. W. and Schienle, J. L., March 1985, "High Temperature Coating Study to Reduce Contact Stress Damage to Ceramics," Proceedings of the Twenty-Second Automotive Technology Development Contractors' Coordination Meeting (October 29-November 2, 1984), SAE P-155, pp. 453-461.

7. Price, J. R., van Roode, M., and Stala, C., 1992, "Ceramic Oxide-Coated Silicon Carbide for High temperature Corrosive Environments," Key Engineering Materials, 7274, pp. 71-84.

8. Price, J. R. and van Roode, M., 1994, "Corrosion Resistant Coatings for Ceramic Heat Exchanger Tubes Operating in Highly Corrosive Environments," Final Report, GRI-940353, GRI Contract No. 5086-232.

9. Lee, K. N., Miller, R. A., and Jacobson, N. S., 1995, "New Generation of Plasma-Sprayed Mullite Coatings on SiliconCarbide," J. Am. Ceram. Soc., 78[3], pp. 705-710.

10. Lee, K. N., Miller, R. A., and Jacobson, N. S., 1995, "Plasma-Sprayed Mullite Coatings on Silicon-Base Ceramics, " US Patent No. 5,391,404.

11. Basu, S. N., Hou, P., and Sarin, V. K., 1998, "Formation of Mullite Coatings on Silicon-Based Ceramics by Chemical Vapor Deposition," International Journal of Refractory Metals \& Hard Materials, 16, pp. 343-352.

12. Haynes, J. A., Cooly, K. M., Stinton, D. P., Lowden, R. A., and Lee, W. Y., 1999, "Corrosion-Resistant CVD Mullite 
Coatings for $\mathrm{Si}_{3} \mathrm{~N}_{4}$," Ceramic Engineering \& Science Proceedings, 20[4], The American Ceramic Society, Westerville, OH, USA, pp. 355-362.

13. Lee, K. N., Fritze, H., and Ogura, Y., "Coatings for Engineering Ceramics"; in Progress in Ceramic Gas Turbine Development, Vol. 2., Edited by M. van Roode, M. Ferber, and D. W. Richerson, ASME PRESS (in press).

14. Lee, K. N., Miller, R. A., Jacobson, N. S., and Opila, E. J., September-October 1995, "Environmental Durability of Mullite/SiC and Mullite/YSZ Coating/SiC Systems," Ceramic Engineering \& Science Proceedings, Edited by J. B. Watchman, The American Ceramic Society, Westerville, OH, USA, pp. 1037-1044.

15. Lee, K. N., 2000, "Key Durability Issues with MulliteBased Environmental Barrier Coatings for Si-Based Ceramics," Transactions of the ASME, 122, pp. 632-636.

16. Haynes, J. A., Lance, M. J., Cooley, K. M., Ferber, M. K., Lowden, R. A., and Stinton, D. P., 2000, "Protective Capacity of CVD Mullite Coatings in a High-Temperature, High-Pressure, Air- $\mathrm{H}_{2} \mathrm{O}$ Environment," J. Am. Ceram. Soc., 83[3], pp. 657-659.

17. Lee, K. N., 2000, "Current Status of Environmental Barrier Coatings for Si-Based Ceramics," Surface and Coatings Technology, 133-134, pp. 1-7.

18. Eaton, H. E., Linsey, G. D., More, K. L., Kimmel, J. B., Price, J. R., and Miriyala, N., May 8-11, 2000, "EBC Protection of $\mathrm{SiC} / \mathrm{SiC}$ Composites in Gas Turbine Combustion Environments," ASME paper 2000-GT-0631, presented at the International Gas Turbine and Aeroengine Congress and Exposition, Munich, Germany.

19. More, K. L., Tortorelli, P. F., Walker, L. R., Trent, K. S., Eaton, H. E., Sun, E. Y., Linsey, G. D., Miriyala, N., Kimmel, J. B., Price, J. R., Ellingson, W. A., Sun, J. G., Landini, D. J., and Craig, P., June 5-9, 2001, "Recent Evaluation of CFCC Combustor Liners with Environmental Barrier Coatings (EBCs) after a $\sim 14,000$ h Engine Test," presented at the International Gas Turbine and Aeroengine Congress and Exposition, New Orleans, LA, USA.

20. Lee, K. N., Fox, D. S., Robinson, R. C., and Bansal, N. P., 2001, "Environmental Barrier Coatings for Silicon-Based Ceramics," High Temperature Ceramic Matrix Composites, Edited by W. Krenkel, R. Naslain, and H. Schneider, Wiley-Vch, Weinheim, Germany, pp. 224-229.

21. Eldridge, J. I. and Lee, K. N., 2001, "Phase Evolution of BSAS in Environmental Barrier Coatings," Ceramic Engineering \& Science Proceedings, 22[4], Edited by M. Singh and T. Jessen, The American Ceramic Society, Westerville, OH, pp. 383-390.

22. Zhu, D., Lee, K. N., and Miller, R. A., 2001, "Thermal Conductivity and Thermal Gradient Cyclic Behavior of Refractory Silicate Coatings on $\mathrm{SiC} / \mathrm{SiC}$ Ceramic Matrix Composites," Ceramic Engineering \& Science Proceedings, 22[4], Edited by M. Singh and T. Jessen, The American Ceramic Society, Westerville, OH, pp. 443-452.
23. Zhu, D., Lee, K. N., and Miller, R. A., 2002, "Sintering and Cyclic Failure Mechanisms of Multi-Layered Thermal and Environmental Barrier Coating Systems under High Thermal Gradient Test Conditions," Ceramic Engineering \& Science Proceedings, 23, The American Ceramic Society, Westerville, $\mathrm{OH}$ (in press).

24. Touloukian, Y. S., Kirby, R., Taylor, R. E., and Lee, T. Y. R., 1977, Thermophysical Properties of Matter, Vol. 13, IFI/Plenum, New York, Washington.

25. Miller, R. A., Smialek, J. L., and Garlick, R. G., 1981, "Phase Stability in Plasma-Sprayed Partially Stabilized Zirconia-Yttria," Advances in Ceramics, Vol. 3, Science and Technology of Zirconia, The American Ceramic Society, Westerville, OH, USA, pp. 241-253.

26. Miller, R. A., Garlick, R. G., and Smialek, J. L., 1983, "Phase Distribution in Plasma-Sprayed Zirconia-Yttria," The American Ceramic Society Bulletin, 62[12], pp. 13551358.

27. Richerson, D. W., 1982, Modern Ceramic Engineering, Marcel Dekker, Inc., New York.

28. Bansal, N. P. and Eldridge, J. I., 1998, "Hi-Nicalon FiberReinforced Celsian Matrix Composites: Influence of Interface Modification,” J. Mater. Res., 13[6], pp. 15301537.

29. Phase Equilibria Diagrams, CD-ROM Database Version 2.1, The American Ceramic Society, Westerville, $\mathrm{OH}$, 1998.

30. H. Wang, B. A. Nagaraj, and I. T. Spitsberg, 2001, "Thermal/Environmental Barrier Coating for SiliconContaining Materials," European Patent Application EP1142850. 